\title{
La doble ajenidad del mundo por escrito: reflexiones sobre la violencia de la escritura a propósito de un diario de campo en Colombia
}

\author{
The double strangeness of the world by writing: \\ reflections on violence writing about a Field journal in Colombia
}

\author{
Santiago Martínez-Magdalena ${ }^{1}$ \\ santiago.magdalena@um.es
}

\begin{abstract}
Resumen
El autor emprende un diálogo de contrapunto consigo mismo y con otros sobre las producciones escriturarias de una estancia de formación en Colombia: específicamente, al hilo de la revisión crítica de un ingenuo diario de campo en el estudio de las prácticas médicas en el Chocó, infructuoso en la producción antropológica, aunque no en las reflexiones académicas y formativas. Después de catorce años de abandono, el diario, revisitado, se resiste a ser leído, presentando al autor primero incomprensibilidad: una doble ajenidad en torno a la valoración antropológica de la violencia en Colombia. Una primera ajenidad experimentada en el campo, y, merced al alejamiento escriturario (como marcador temporal), una segunda ajenidad de lo escrito, que se resiste a ser reinterpretado de manera coincidente con la primera lectura anterior. La violencia cometida al pretender la inteligibilidad sobre lo propio escrito en otro lugar por otro-mismo, sobre lo experimentado escrito y dejado al tiempo, revierte en metáforas pertinentes al reflexionar sobre una violencia en Colombia que deviene en una violencia de la escritura sobre Colombia.
\end{abstract}

\section{Palabras clave}

Violencias de la escritura, epistemología antropológica, reflexibilidad etnográfica, diario de campo, Colombia.

\begin{abstract}
The author dialogues with himself and with others on ethnographic productions training stay in Colombia: specifically, critical review of a Field journal studying medical practices in Colombia. An unsuccessful outcome, but it was useful in academic reflections. After fourteen years of neglect, the Field journal is revisited, but incomprehensible: shows a double alienation, and is unable to assess the violence in Colombia. A first experienced alienation in the field, and in the distance, a second strangeness of writing, that refuses to be reinterpreted. These considerations allow us to see that violence in Colombia is actually a script violence on Colombia.
\end{abstract}

Keywords

Violence writing, anthropological epistemology, ethnographic reflexivity, field journal, Colombia.

Forma sugerida de citar: Martínez-Magdalena, S. (2015). La doble ajenidad del mundo por escrito: reflexiones sobre la violencia de la escritura a propósito de un diario de campo en Colombia. Universitas, XIII (22), pp. 37-70. Quito: Editorial Abya-Yala/ Universidad Politécnica Salesiana.

1 Doctor en Filosofía-Antropología social y cultural, UNED, Madrid (España). Docente de la Universidad de Murcia (España), departamento de Filosofía, área de Antropología social. 


\section{Mundos de escritura}

Antropología e historia, sociología y ciencias sociales y humanas, en fin, se constituyen en regiones disciplinarias (ámbitos como eufemismo) que atesoran universos objetuales. Dadas las características de conformidad de estos objetos (sociales, culturales, políticos), epistemológica- y teóricamente construidos, y asumidos metodológicamente, no podemos dejar de ordenarlos cartográfica y tropológicamente con "geografías y etnografías objetuales" (Martínez Magdalena y Gómez Quintero, 2007), si así pudiéramos hablar. La Antropología es precisamente un "saber diferenciado" que debe ser entendida en su producción histórico-disciplinaria (Menéndez, 2002: 32 ss.). Desde los mapas que ordenan el conocimiento en "campos" (terrain) de la Encyclopédie (Burke, 2002: 117), el Mundus Intellectualis de F. Bacon (Sylva Sylvarum, A Natural History, 1627; e Instauratio Magna, 1620) acoge la metáfora de los nuevos territorios progresivos, permitiendo al investigador ser un Colón intelectual, propicios para la provisión de un conocimiento de descubrimiento y conquista (Burke, 2002: 147 ss.). Toda esta metafórica está reunida con precisión en el "campo" y sus "poblaciones" (el campo poblado): una colonización epistemo-eurocéntrica que hoy debe ser desobedecida (Mignolo, 2011); lo que puede suponer algún tipo de "destierro determinado" de los otrora soberanos ostracidas.

Esta ironía recoge por escrito, nótese, algo más que una simple transposición de sentido. Por lo común, son dos entidades distintas (mundos disciplinares, el mundo disciplinado), que se superponen, la primera sobre la segunda, de una manera decisiva en la historia del conocimiento occidental. A este tenor nos parecen interesantísimas las representaciones de los hombres de saber y los regímenes de sabiduría y prevención del desvío heterodoxo en la contrarreforma (De la Flor, 1999: cap. III). Y que delimitaría lo que es lícitamente cognoscible y lo que no lo es: ámbitos expertos y populares, y regiones de sombra arrinconadas por las jerarquías.

Su crítica apenas ha afectado a nuestras disciplinas, ni en su revisión epistemológica ni, por tanto, en sus desarrollos metodológicos. Como mucho, aparte de la manida discusión entre realismo, naturalismo y reflexividad (Hammersley y Atkinson, 2003: cap.1), la clásica distinción entre oralidad y escritura, estructura y acontecimiento, y Memoria e Historia. Sigue subrayándose aún el distingo emancipatorio de la ciencia respecto de una realidad y una verdad que no por diversas (realidades y verdades) dejan de conjeturarse siempre sediciosas hoy, como supersticiosas ayer. Lo propio ocurre con sus objetos, que se constituyen 
también a la manera de pacientes orgánicos con una extensión criterial sociológica cara al nacionalismo y el liberalismo: pueblo, comunidad, sector, clase social, individuo/persona/sujeto, práctica social, autonomía y agencia deliberativa, red, norma, institución, etc. Aunque éstos sean considerados hoy múltiples y de perímetros más difusos, no acaban de procurarnos mejores horizontes teóricos, al menos, que no sean simplemente nihilistas (correlato eufemístico de la disidencia) o, contrariamente, de desplazamientos metafóricos prácticos pero precisos.

Contaba Óscar Calavia en la UNED (en una conferencia en Madrid, 16-12006, Facultad de Filosofía) la imposibilidad de rivalizar con sus compañeros de doctorado en la comparación de los ritos de sus respectivos indios/objetos: los Yaminawa (entre Brasil y Perú) en su caso. Concretamente, el problema teórico que suscita esta etnia que "se niega a ser india" en los cánones indigenistas que la antropología o la política regional ha marcado para ella, decía. La pérdida de la jerarquía tradicional o la organización social de los Yaminawa (Calavia, 2002), así como muchos de sus ritos, etc., y su única tendencia monotemática (que sería identitaria) hacia el viaje a la ciudad, los paseos y la observación del movimiento urbano desde la acera, y el consumo de alcohol. Lo único que requieren de la civilización es así un medio de autodestrucción, o el escaparate del espectáculo urbano, lo que los ha convertido en un problema de intervención social fracasado en los servicios sociales u ONG; en unos bárbaros entre los bárbaros, o en unos blancos en la denominación por parte de otras etnias. Así, esta negación a convertirse en indios supone la renuncia a participar del mercado simbólico de la indianidad. Calavia expresará que esta etnia (si acaso definida aún por la lengua, aunque común a otras etnias, y el nombre) no carece de normas, ni aun de cultura pese a autodefinirse como anómica o "sin cultura", en sus propias palabras prestadas por el léxico socio- y etnográfico. Sino que responde más bien a un exceso de normas y cultura: en el sentido de que en su seno existe una disputa entre distintos órdenes de poder: mujeres y hombres, viejos y niños, mercantilismo y tradicionalismo, etc. Pero además debido a la superproducción etnográfica, que casi actúa como rigorista de aquella normatividad antigua.

Por tanto, concluimos nosotros, ante esta situación podemos plantearnos un fracaso no tanto de la teoría o el método etnográfico cuando del objeto. El que los Yaminawa sean hoy los verdaderos salvajes (los salvajes entre los salvajes) por negarse a seguir entrando en la horma prefabricada del indio antropológico no acaba de esconder este fracaso del objeto. Esto supone dejar de preguntarse 
o refinar de continuo el método y la teoría, para preguntarse más por el objeto mismo y su construcción, y cómo aquellos se pliegan a éste, que obedece más no tanto a otras cuestiones (como la política o las servidumbres de la ciencia social), sino al mismo problema identitario-profesional de nuestra ciencia.

Los embates del postestructuralismo, el postmodernismo, la post- y decolonialidad, el activismo, la deconstrucción, la Teoría Crítica, y la filosofía, sociología, economía e historiografía de la ciencia hace que hoy nos cuestionemos estas vicisitudes estancas de manera diversa pero convergente, y nos incorporemos como conciencia crítica y propósito político ${ }^{2}$, sujetos/objeto y viceversa, donde aparece, siquiera como horizonte teórico, la posible renuncia al estatuto profesional. Pero, aún más, donde esa realidad y verdad, plurales y decolonizadas entonces se motoricen, en un desplazamiento de los objetos, movilizados por nuestra propia práctica. Las verdades y realidades no pueden ser simplemente diversidad parida de una universalidad previa pero dimitente; sino desagregación histórica. Lo que implica necesariamente preguntas por la intencionalidad, el planeamiento, los efectos calculados y perversos, de nuestra práctica en el campo y nuestra teórica, en la emancipación del objeto: que camina e interpela.

Partimos por tanto de un campo reconceptualizado como archivo clasificatorio que debe desanudar los objetos desde el conflicto colonial. En nuestro contexto indagatorio inmediato, el "campo" (Archivo que debemos ir abandonando) surge como pliegue perimetral de la disciplina, arrastrando consigo una retahíla de metáforas más o menos consolidadas por la teoría y la práctica etnográfica, encarnadas performativamente, escenificadas ${ }^{3}$; pero que suponen sobre el mismo "campo" procesos de vaciamiento de lo que ni es ni puede ser un campo, y, consecutivamente, de relleno no sólo de contenido, sino de la variación nilótica que lo determinan como espacio poblacional: lo que sí es y puede ser nuestro campo, porque abrir un campo es espaciarse, colonizar, poblar, territorializar el conocimiento en la administración de sus dimensiones.

Describir lo observado en estos campos poco neutralizados, poco pacificados, de poblaciones silvestres, nos arroja a la labor escritural o política. Un cuer-

2 Un "hacerse cargo" en la administración de la herencia no puede tener otro propósito rehabilitador que la decolonización, único objetivo reparador. Una conciencia crítica no supone un "perder la conciencia" irresolutivamente, sino un "recuperarla en la desagregación histórica de lo recibido".

3 Nótese que de ir abandonándolo no podemos sustituirlo simplemente por su ridículo antónimo urbano, aunque sí poblacional, que denuncia la intención colonial. 
po formativo que inviste o donde se inviste la autoridad etnográfica. Planta el descriptor (neutro burócrata) como otra máquina menos discreta: la autoral que se hace cargo. Que se desviste. O que se viste a los ojos de los que nos interpelan. Aquí reside la polémica del narcisimo acusador de una postmodernidad maligna y sus retóricas. Sin embargo, queda en evidencia, si asumiéramos esto, la necesidad de revisitar el concepto de intimidad y pudor, por un lado, y la elevación del edificio yoico, por otro; todo ello en la relación entre cuerpo, presencia, y texto de dominación. El cuerpo [expuesto] como texto de dominación no es precisamente narcisista en el dolor barroco, sino una estrategia de pensamiento.

Todo esto nos conduce a la experiencia de investidura autorial, a la socialización académica en nuestro caso ${ }^{4}$. Declarar los fracasos de investigación es una pose calculada, la misma, o su reverso, que instrumentaliza el extrañamiento carnal en el campo etnográfico (Velasco y Díaz de Rada, 2003). Hacemos de "nuestro" campo un caso, una posesión ${ }^{5}$, donde reside el nosotros como autoridad que administra poblaciones ficcionalizadas en una práctica real. Debemos, por tanto, exponernos, ejerciendo una violencia primaria en el narcisismo acusatorio instrumental. Y así, con esto, "decir-nos". Aunque enseguida trataremos de nuestro tiempo en Colombia, nos importa asumir la socialización profesional que nos llevará a aquel campo remoto desde el nuestro nativo que nos exige nuevas y más poderosas investiduras (Martínez Magdalena, 2000). Titulábamos un trabajo nuestro, inconcluso ${ }^{6}$ " "Marco, escena y campo. Espacios y tiempos de sociabilidad experta en la ficción identitaria regional española" (Martínez Magdalena, inédito) ${ }^{7}$ en el intento por reflexionar sobre los fenómenos solidarios e intrincados que se estarían dando a la par en nuestra socialización académica e investigadora (y que de ningún modo pueden segregarse de

4 No pretendemos aquí sentar conceptos nuevos, ni relacionar estrechamente un trabajo de campo puntual que resulta anecdótico con la teoría. Trabajamos más la teoría a propósito de nuestro itinerario formativo, con un claro sentido heurístico, no desde fuertes bases empíricas, puesto que el mundo empírico, como cosa real, lo problematizamos igualmente. El lector notará una fuerte tensión entre la delgadez anecdótica de la experiencia en el campo y la fuerza avasalladora de una teoría-letra que todo lo coloniza como ejercicio de violencia. Acusar a lo primero, al diario de campo, de vanidad narcisista es declararlo víctima. Se trata de un dispositivo político nada ingenuo en realidad.

5 Pedimos disculpas a los lectores y lectoras por citarnos e incluir una nutrida auto referencialidad bibliográfica. Sin embargo, insistimos en acusar ese narcisismo como recurso, atravesando necesariamente nuestro itinerario formativo-productivo, frente a una modestia escondida en la comunidad científica, en caso contrario, que sería igualmente instrumental y calculada.

6 Como falso fracaso o fracaso instrumental.

7 Que sea "inédito" lo hace neutro, no expuesto, y permite al autor una ventaja de ficcionalización preventiva y no prevadicadora. 
nuestra continua socialización ciudadana y personal) y el impacto real, seguramente modesto pero igualmente difícil de calibrar, que nuestro trabajo tendría en la sociedad objeto de nuestro estudio, que en este caso no sería otra que la "nuestra" si el propio origen puede, de por sí, dejarse apoderar por nuestras pinzas disciplinarias, y otorgarnos identidad: entonces se daría el desplazamiento hasta "nuestro campo". Respecto al "impacto", lo decimos así porque, en nuestro trabajo etnohistórico en España, se vio pronto cómo se intervenía en el campo (con mayor o menor poder de influencia) al lidiar el autor, por ejemplo, en la prensa regional con artículos de opinión política en momentos puntuales. El objeto, decíamos entonces, se configura en ámbitos virtuales donde se detiene el paisaje, la historia, la economía y la política, etc. (marco, contexto), se observa el cambio histórico (escena) y se participa (con visos analíticos) en la actividad grupal (campo). La ficción territorial, paradójicamente, se constituye así como entramado de espacios y tiempos donde el perspectivismo del observador y su relato (lector, público, participante o actor) cambian, y donde se socializan asimismo los expertos. Así, el objeto se transpone como un meta-espacio intelectual (marco, escena y campo) donde el actor se socializa y toma identidad, y donde esos girones y fragmentos se promueven precisamente en la tarea de socialización de los expertos (etnógrafos y etnólogos, historiadores, geógrafos, sociólogos, politólogos, etc.) que contribuyen paradójicamente a ampliar sus espacios no ya sólo de investigación o designación intelectual, sino precisamente aquéllos con los que se identifican por distintas razones: de uso disciplinario, simpatías, vindicaciones de identidades y justicia social, etc.

Además, nos interesará documentar la pretensión totalizadora del proceso socio- y etnográfico sobre este objeto que, de puro plural, se convertirá en un Mundo que, consecuentemente, al dejarse por escrito, lo abarca todo (o tiene pretensiones de hacerlo $)^{8}$, requiriendo múltiples interpretaciones y discusiones subsiguientes, albergando entonces muchos y, en definitiva, todos los mundos. Entendidos además como relación consecutiva de encadenamientos interpretativos. Asumimos que esta interpretabilidad infinita (ya baconiana) ${ }^{9}$ no recae

8 La cuestión del "holismo", a partir de los hechos sociales totales maussianos que hace al individuo "relacional" e "institucionalizado", sigue siendo muy debatida. Ha procurado un método como actitud holística de carácter indagatorio sobre objetos difusos, en la cual, esas relaciones sociales son "instrumentalizadas" por el etnógrafo para producir conocimiento (Velasco y Díaz de Rada, 2003).

9 Las propias "cadenas Etic0 $>$ Emic0; Etic1 > Emic1...; Eticn $>$ Emicn à Saturación = Arbitrio cultural o convención" de la investigación etnográfica (Velasco y Díaz de Rada, 2003), muy verticales, abrirían posibilidades interpretativas horizontales (Martínez Magdalena, 2007). 
meramente sobre la primera labor escrituraria. Sino que, además, la producción de su análisis histórico y contextual sobrepasa el tiempo de la epistemología que sustentaba ese quehacer; quedando atrás entonces el objeto, con menor importancia en la reflexibilidad teórica posterior: casi testimonial por cuanto ahora importa la crítica del método. Pero que, por este mismo motivo, el objeto se re-escribe y violenta, acaso como remanente, plusvalía u objeto secundario o subscrito al debate teórico y metodológico. Los objetos, por tanto, quedan como exempla no tanto de una realidad cuanto producto moral, resultado exento de la aplicación metodológica y caso del refinamiento teórico. Esa casuística querida por el antropólogo español Julio Caro Baroja. De ahí la acusación de ciencia social inservible, poco útil a la operatividad sistémica; tachada la antropología de exceso de escrúpulo, de moralidad cívica, de política activista y antisistema ${ }^{10}$. La corrección de estos mundos sería pues detenida por el carácter disciplinario (nunca mejor dicho) de la metodología, desdeñándose aquellos otros mundos etno- y sociográficos no atenidos a la regla productiva, no designados por la "visión" metodológica y su recta aplicación. Sin embargo, sabemos que tanto la realidad mundana como el fracaso mismo de la ciencia (que se debate en la construcción de falsificaciones de prestigio) rompen muy a menudo el método, haciéndolo saltar en pedazos.

Sea como fuere, nos parece que el debate sobre los "mundos posibles" como "fábrica de fenómenos" (Sandkühler, 1999), que parecerían caber todos en un tratado general del mundo clasificatorio o instituido (universal, científico), como parte del proyecto ilustrado enciclopédico, pero antes más diluido en la literatura de viajes y la paradoxográfica (Martínez Magdalena y Gómez Quintero, 2007), ha sido aún infructuoso en la incorporación a las ciencias sociales y humanas. Paradójicamente. Y lo decimos así porque en la teoría y la práctica escrituraria de estas ciencias están muy presente viejas metáforas (Blumenberg, 2000; Olson, 1998:§8) que como restos flotantes de pasados naufragios emergen y se sumergen para emerger de nuevo en un vago parapeto mixtificador. Es el caso de las "imágenes" (a menudo como sucedáneo de "representaciones", "cuadros pictóricos", "resúmenes generales"); usado profusamente en la historiografía y las ciencias sociales, pero muy desasistido teóricamente (Martínez Magdalena y Gómez Quintero, 2007). No obstante, autores como Sandkühler

10 De ahí, en muchos casos, su tardanza en la vanguardia de los cambios sociales, su ir detrás, en pos de un objeto que se mueve adelante; su dedicación escuálida a seguir los acontecimientos, las cosas dadas, limitándose a describirlas y holgar en abstracciones culturológicas. 
(1999: 64), prefieren imagen a visión, asumiendo que la imagen da a entender la autoría constructiva. Por otro lado, es posible criticar la optométrica o régimen escópico de la etnografía, producto del iluminismo de la "Observación" participante (Martínez Magdalena, 2013 y 2014). Aunque nos va a importar esto mucho menos, nos queremos referir aquí a la pretensión de recoger por escrito una realidad y una verdad que podemos defender hoy como compleja, intrincada y diversa (mundos plurales), pero que continua considerándola aprehensible sólo de manera unívoca. Aunque identifiquemos regiones diversas, geográfica y etnográficamente distintas, el método-mapa y el instrumento-navío es uno y el mismo (Martínez Magdalena, 2000), con visos de universalidad nepótica pero sin potencia constructiva emancipatoria, es decir, sin potencia de intrincación, propulsora de complejidad o emancipadora en su diversidad: lo que supondrá, de facto, la comprensión de la constitución de subjetividades locales.

\section{La ida y la vuelta de la escritura: un breve método}

Entre verso y recto, el pliego, como el resorte práctico del contenido espiritual de la letra, responde a un método preciso de plegado. Aunque breve, la estrategia analítica que emprendemos aquí tiene un recurso principal y uno auxiliar: En primera instancia, la relectura de nuestro diario de campo en Colombia tras catorce años de abandono e improductividad ${ }^{11}$; en segundo lugar, el auxilio puntual de los diálogos y productos compartidos con un autor colombiano investigador y docente en España, cuyo itinerario se inicia precisamente en nuestro encuentro en Medellín (Gómez Quintero y Martínez Magdalena, 2005a y 2005b). En la discusión de dos autores de universos distintos (tanto cultural como disciplinariamente: nuestro interlocutor hace trabajo sociológico sobre las ONG españolas en Colombia), llegaremos, al hilo de nuestro diario de campo, a discutir la posibilidad de mundos emancipados, segregados y autónomos a partir del impulso investigador. Que, en verdad, no es más que un motor de cambio social/ objetual; es decir, de transformación definitiva del objeto de estudio en agente propulsado en la misma (o aparentemente idéntica) esfera social. Es posible así emprender un diálogo de contrapunto en torno a la estancia del primero en Colombia y la del segundo en España. Nosotros, específicamente, al hilo de la revisión crítica de un diario de campo a propósito de una estancia de investiga-

11 Publicamos simplemente un artículo más poético que otra cosa (Martínez Magdalena, 2000). 
ción para estudiar las creencias y prácticas médicas de población indígena, afrocolombiana y mestiza en el Chocó. Que fue derivando imperceptiblemente, por cierto, hacia claras consideraciones sociopolíticas (no sabemos si por un traslado del interés del observador o por la emancipación del objeto de estudio, así impulsado), al hilo de las situaciones y personajes que en él se recogen por escrito. Cuestiones que requieren reflexiones epistemo- y metodológicas consecuentes. Después de catorce años de abandono, el diario, exhumado de un cajón (Martínez Magdalena, 2006), se resiste a su lectura, presentando al autor primero una doble ajenidad en torno a la valoración antropológica de la violencia en Colombia: una primera ajenidad experimentada en el campo, y, merced al alejamiento escriturario (como marcador temporal), una segunda ajenidad de lo escrito, que se resiste a ser reinterpretado de manera coincidente con la primera lectura anterior. La violencia cometida al pretender la inteligibilidad sobre lo propio escrito en otro lugar por un otro-mismo, sobre lo experimentado escrito y dejado al tiempo, revierte en metáforas pertinentes al reflexionar sobre la violencia en Colombia y sus pretendidos postulados locales y globales, y es precisamente esa ajenidad- la que nos impele sobre la emancipación y potenciación del objeto (la salud en el Chocó, que deviene, finalmente, cuestión política). La ida y la vuelta y la vuelta y la ida (Martínez Magdalena, 2000), entre dos investigadores distintos con trabajo de campo en Colombia (colombiano y español) ${ }^{12}$, por último, permite acometer un entramado discursivo interesante que arroja luz sobre la práctica investigadora (etno- y sociográfica) ${ }^{13}$.

Es decir, no hemos trabajado solos. Además, lo hemos hecho posicionados, aprehendiendo, si esto es posible, una Colombia desde su definición como lugar de violencias. Cuya narratividad producida es incapaz de ser descriptiva de un concepto preexistente, la violencia, o la mismísima Colombia como nación.

\section{La escritura y la voz: violencias de la escritura que acallan la voz}

En el proceso socioetnográfico podemos describir varios actos procedimentales de violencia escritural. La primera, cognitiva: planes de investigación;

12 Ya hoy, en verdad, ambos, con identidades de ida y vuelta: hispanoamericano el primero y colombohispano el segundo. Lo que dice mucho de los objetos de estudio "desde" las identidades estudiosas.

13 La relativa o auxiliar "ausencia" discursiva del segundo investigador debe revelarse en sus propios discursos, que pueden seguirse en sus muchas publicaciones. Aquí solamente haremos mención de los trabajos en común y los diálogos asimilados por el primero. 
motivaciones prejuiciosas, intereses bastardos de investigación; la segunda, la presencia del etnógrafo en el campo en persecución maussiana y malinowskiana de su objeto; posteriormente, la interpretativa y reinterpretativa; por último, la violencia de la publicación monográfica o los efectos, no sólo textuales, de su quehacer e intencioanalidad, más o menos emancipatoria del objeto/sujetoactor. Es lícito pensar que estas ciencias incurren en la explotación procedimental de los "informantes", en lo que se ha venido llamando "industria extractiva" (Castillejo Cuéllar, 2009) e "industria del diagnóstico” (Jaramillo Marín, s. f.). Pero a todo esto, hay que añadir la motorización del campo. Es decir, el proceso que impulsa a la acción del actor y a la movilización del entramado sociopolítico estudiado, que se manifiesta ya en la secuencia segunda: suponiendo que la primera sea impoluta; aunque la presencia previa del etnógrafo en la biblioteca o el archivo -ya no hablemos si hay prospección sobre el terreno- es ya enigmática. En el primer caso, en nuestro trabajo de campo sobre una zona selvática colombiana, pudimos comprobar cómo existen intensos planes autóctonos de desarrollo, intervención y ordenación territorial, municipales, departamentales, regionales, diseñados por distintos especialistas y técnicos (entre ellos, antropólogos y sociólogos) ${ }^{14}$; trufado asimismo de intervenciones internacionales (ONG, ONGD, etc.). Si bien nos parecieron, irremediablemente, en los mismos parámetros de homogeneidad de conocimiento desde las instituciones de emisión: universidades, etc.; desde la mirada urbana institucional y central: institutos estatales y entidades privadas, etc. Pero aún más, desde la misma teoría. Es decir, no existía ningún vacío cognoscente, ni tampoco práctico, sobre la zona, si bien es necesario recalcar, por lo mismo, que la exuberante presencia de documentación etnohistoriográfica es precisamente la que, por el celo de etnógrafos, historiadores, etc., alimenta la identidad local (González Escobar, 1999). La inexistencia de tal vacío cognoscente sobre ese territorio responde precisamente al afán temprano colonial, a la necesidad de reificar una identidad territorial o territorializada inmediatamente, y a la reorientación cognitiva actual (Escobar, 1996 y 1999). Los planes de nuestra travesía de investigación, por lo demás, estaban bien pertrechados, tratándose de relevar la documentación necesaria para caracterizar el Darién colombiano con vistas a una valora-

14 En un estudio de campo posterior por el Gran Chaco en 2015, pudimos comprobar asombrados la hiperproductividad antropológica sobre pueblos indígenas. En cualquier comunidad topábamos con antropólogos y antropólogas, muchos insertos desde misiones evangélicas y católicas, y ya hoy, afortunadamente, indígenas. Los primeros ventrílocuos, si bien es necesario defender su labor activista. 
ción ecológica con parámetros de sustentabilidad futura en la ordenación del territorio (Uribe, 1998 y 1999). Nosotros contribuimos modestamente al relevamiento sanitario (Martínez Magdalena, 1999). La violencia de este proceso, en fin, recaería en el prejuicio construido en torno a las dificultades del viaje y el relevamiento (Martínez Magdalena, 2000), así como en los implementos teórico-metodológicos. Respecto a la segunda violencia, la presencia del etnógrafo en el campo llevará aparejada una retahíla de procedimientos de calculada pero inefectiva prudencia metodológica y experiencias fuertemente vividas (Martínez Magdalena, 2000) que llevarán a un ensayo teórico (Martínez Magdalena, 1999), pero donde el Diario de campo se mostrará inoperante, ineficaz, estando abocado a una desadaptada fuente posterior necesitada de interpretación y reinterpretación. En 2005 habíamos escrito con una infumable retórica novelesca:

Encontrándose el autor en 1998 atravesando la selva colombiana del Chocó en la frontera panameña, en una expedición antropológica universitaria, sus compañeros de campo, eminentes y curtidos investigadores -alguno premio nacional de su país; no será menester alabar aquí la extraordinaria calidad de la antropología colombiana-, le llevaron, como en un privilegio académico, a ver, para entrevistarla, a una ancianísima mujer de un remoto poblado de la costa caribeña. Le dijeron al autor que esa mujer era una de las mejores informantes de la zona, no sólo por su mucha edad, sino por su gracia y conocimientos, unos conocimientos que se asemejaban a las genealogías del Macondo de Gabriel García Márquez. Es fácil imaginarse las expectativas de quien esto escribe; así como la consideración del esfuerzo por atravesar peligros sin cuento y recorrer mucha distancia en pos de esa informante ${ }^{15}$. Pues bien, esta señora estaba en la cama, casi inmóvil, cuando llegamos a su cabañita playera. La hicieron levantar -estaba sola, su sobrino apareció después-, y la sentaron frente de mí para que le preguntara cosas (¡tenía tantas en mi guía de entrevista!, ingenuamente). La anciana estaba adormilada, y poco lúcida. Apenas se la entendía, aunque con ayuda de mis compañeros -por la cuestión de los acentos y los giros idiomáticos-, pude comunicarme con ella. Además de los escrúpulos que sentí de inmediato,

15 Evidentemente, a buen seguro que, en "zona de guerra" (recordemos "la situación" colombiana), hubo itinerarios que estaba recomendado hacer (o se podían hacer con un riesgo aceptable) y otros no. Del mismo modo, esa anciana debió constituir en el pasado una buena informante para estos compañeros etnógrafos. Sin estas condiciones, no cabría entender este esfuerzo ingenuo (para todas estas vicisitudes vide Martínez Magdalena, 2000). Sea como fuere, se entiende como el mito profesional recurrente en los autores noveles, difícil aún de combatir desde las cátedras formativas, que niegan lo que cuentan y experimentaron sus voceros. 
me vino a la memoria lo que meses antes me había pasado, como a muchos antropólogos (es un mito), con una informante autorizada en España: que, preguntándole por una cuestión concreta, me dijo que espérese un momento; sacó una revista local en la que había sido entrevistada y en la que un periodista le había hecho la misma pregunta, y ¡me leyó la respuesta! Y, por supuesto, recordé también lo que había aprendido sobre las urgencias de la (escuelas etnológicas y folklóricas europeas)... por recoger los vestigios de una sociedad periclitada...

Más aún, porque ternura e ingenuidad son cosas políticas:

Pues bien, volviendo a Colombia, sólo le pregunté a aquella anciana ilustre por una cuestión biológica puntual, como constaba en mi entrevista de campo: la investigación trataba de documentar las prácticas curanderiles de las comunidades afrocolombianas, indígenas y mestizas de la zona. Después rogué a mis compañeros que la volvieran a acostar ${ }^{16}$. A partir de aquí se desarrolló una discusión acerca de la incisividad de los etnógrafos sobre los informantes para producir información, lo que me volvió a acontecer años más tarde, en otro contexto (Argentina y patrimonio indígena), $\mathrm{y}$, aunque con menos intensidad, sobre la supuesta “deficiente explotación” por mí de mis informantes. Pues bien, reparos aparte, faltas de habilidad o de curtido, o lo que se quiera, más tarde en Colombia pude completar mis conocimientos a través de otros testimonios mucho menos autorizados y hasta desechados: unos niños jugando en la playa me contaron sus terrores comunes - posteriores encuentros, con dibujos, entrevistas, etc., entre madres y niños fueron de una riqueza majestuosa-, y la taberna local fue un excelente lugar para consolidar mis conocimientos ${ }^{17}$. Nótese el contraste, de la anciana que se va del mundo atesorando recuerdos y saberes incomensurables, que es necesario agitar cuanto antes, a la creciente y proyectiva comprensión del mundo por unos niños que nacen a la verdad socializada. Es claro que lo uno no quita lo otro, y que ni los niños pueden documentar cosas que se les escapan por la naturaleza de su generación (¡qué de cosas dejé de saber por no zarandear a la anciana!), ni los ancianos pueden abarcarlo todo (amén de problemas de memoria $)^{18}$. Y tampoco me refiero a los meros escrúpulos sociopolíticos, mora-

16 Nótese cómo se salva el autor.

17 No todo esto fue apuntado y recordado en el Diario de campo, por supuesto, que no deja de ser inadecuado y una doble construcción desplazativa del sentimiento en el supuesto intelecto escritural. La ficcionalidad de lo acontecido, el encuentro o desencuentro, y lo apuntado y recordado son tensiones necesarias.

18 Es notorio que no me estoy refiriendo a la demencia senil precisamente, sino a los procesos de construcción individual y colectiva del pasado rememorado. Nos parece importante subrayar la cuestión de que los informantes, ahora mejor como testimonios, es un problema teórico, con graves consecuencias metodológicas, de primer orden, aún por estudiar. 
les o metodológicos del etnógrafo. Me refiero, en realidad, a la dignidad y la validez de los distintos ángulos u oquedades experienciales y vitales, que no siempre son tomados en consideración, y que no siempre pueden ser reducidos a una sensibilidad etnográfica o social en la transversalidad de género, clase social, generación, etnia, etc.; y, a la vez, me refiero a la negociación (entre etnógrafo e informantes como asunto de transmisión cultural intergeneracional, interclase, género, socialización, cultura, etc.) de lo transmitido, del dato, de la información, que es otra más amplia y compleja que la simple gestión de lo dado. Ésta no puede acabar sino en la asunción del tópico (sea uno u otro, incluido el del propio sistema de indagación) (Martínez Magdalena, 2005: s. p.).

Del resto de violencias correlativas, en fin, nos ocupamos inmediatamente con mayor detenimiento. Sin embargo, preferimos considerar antes una reorientación del estatuto del profesional en el campo. De manera crítica, podemos especular con el trabajo de campo (incluso entendido como mérito académico) ${ }^{19}$ como la proyección/exclusión-expulsión del sujeto observante de su comunidad de origen (que no entiende ni le entiende), que llega a redactar un texto (retórico por lo demás, aunque con la retórica propia de su neo-comunidad disciplinaria o académica) producido desde el ensanchamiento de un espacio exilar, dis-locado, con ese cuerpo (entreverado de textualidad y física) que se posee pero no se quiere, fragmentado como está y puesto a disposición de esa nueva comunidad que lo lanza al exilio, para conocer los modos en que la identidad se escinde y se busca. De hecho, este observador exilar trabaja a cuenta de su comunidad de origen, como especialista en deslindes y trazado de contornos (desterrado autorizado, expatriado). Y así es como mientras no se desembarace de su dependencia académica, pertenece a una comunidad de especialistas en estas lides, autorizada por su sociedad. De esta manera, esta sociedad centrífuga no se establecería solo por la alteridad, sino, solidariamente, por su definición especializada, por sus cuerpos exiliados, ubicados no solo en la alteridad, sino también en una identidad dis-locada/lizada: no tanto por las negritudes raciales, primitivismos culturales, subdesarrollos económicos, y dictaduras-comunismos-populismos democráticos, etc., sino, más bien, por la ausencia

19 Es ya clásico considerar el quehacer del antropólogo y el trabajo de campo como una mitologización, un viaje de paso (rito académico) y la construcción de un héroe científico (méritos académicos), etc. (Stocking, 2003:43 ss.; cfr., en nuestro contexto bibliográfico, el ejemplo de Lévi-Strauss, 1970). Pero deseamos hacer una crítica más consistente respecto al poder y la labor de las ciencias sociales como fuente de autoridad y designadora de realidades (incluso críticas). 
acá y presencia allá de sus especialistas ${ }^{20}$, que se constituyen, propiamente, en las fronteras de esas diferencias. Especialistas (antropólogos)-cuerpos exilarestextos-frontera, o "especialistas-frontera". Los objetos exóticos no nos vienen dados a los museos, sino que son traídos, clasificados, expuestos, etc., por esos especialistas (Martínez Magdalena, 2014). En nuestro mundus intellectualis, esos especialistas son algo más y cosa diferente que meros sujetos a-sociales, marginales o liminares; son, sobre todo, agentes (activos, especialistas expertamente socializados $)^{21}$, y, por tanto, sociales: misioneros, antropólogos y científicos sociales, y, hoy, cooperantes, voluntarios y turistas; que no son éstos menos especializados ni carecen de una socialización que nos aventuraríamos a definir como experta o aún profesional. Ahora bien, especializados, ¿en qué? La categoría exilar es el escribano de un sujeto encendido: un notario que acalla la voz por medio de los flagelos de la escritura.

Ciertamente, los Diarios de campo, como, en fin, cualquier dispositivo metodológico de las ciencias sociales (en el ejercicio etno- o sociográfico), son expuestos como tales elementos de producción de información (textual), que reducen y plasman la complejidad social "por escrito". La patrimonialización de los investigadores que hacen de la cultura una transmisión escrita, codificada/compilada de la cultura (estructuras sociales, estratigrafía, etc.), es raramente estudiada. Lo que acaba, irremediablente, en política (Hammersley y Atkinson, 2003), dado que todo texto es político, al menos por pedagógico y moralista ( $c f r$. Menéndez, 2002). Sea como fuere, y pese a que en ocasiones la antropología y las ciencias sociales en general puedan reconocer su insuficiencia, el texto (más antropológico) pretende, nada más y nada menos, explicar el mundo (lo social y cultural) por escrito, sin reparar en que el propio escrito es un acto político que, por tanto, conforma esa región sociocultural. Como titulara un capítulo C. Geertz en El antropólogo como autor (1997: cap. 2), "el mundo [entero cabe] en un texto". La alusión a los mundos experienciales que devienen escriturarios en el traslado temporal (ajenidad reinterpretativa) es reiterada en nuestra disciplina. Lévi-Strauss ya había escrito: "[La comunicación no obstante es posible entre la experiencia y el conocimiento.] 'Cada hombre -escribe Chateaubriand- lleva en sí un mundo compuesto por todo aquello que ha visto y amado, adonde continuamente regresa, aun cuando recorra y parezca

20 No tanto de sus objetos, que serían portados por estos, como ya señalara Bartra (1996).

21 Recuérdese que nuestra propuesta del agente exilar es, por su propia condición diaspórica, político (transterrado, en referencia al terrain o campo). 
habitar un mundo extraño'. Desde entonces, el acceso es posible. De una manera inesperada, entre la vida y yo, el tiempo ha tendido su istmo; fueron necesarios veinte años de olvido (y distancia) para encontrarme frente a una experiencia antigua cuyo sentido me había sido negado y su intimidad arrebatada por una persecución tan larga como la Tierra" (Lévi-Strauss, 1988: 47-48). Incluso dentro del discurso de las resistencias a la globalización se contienen estas metáforas. Moreno (2004: 514) habla de la glocalización como instrumento para alcanzar "otro mundo en el que sean posibles mil mundos dentro de un marco de reconocimiento e igualdad". Ahora bien, reconociendo la parcialidad crítica de nuestra labor, podemos resituar esta pretensión como "El libro de todos los mundos". El texto donde se pretende que quepa todo el mundo, que deviene en varios o múltiples, o todos -manteniendo esta pretensión totalizadora- los mundos. No hay otro mundo, así que no sea el nuestro y sus lindes, el que nosotros dejamos por escrito, del que damos fe; de ahí el afán supratestimonial del antropólogo, notarial más bien. Este mundo es rememorado, seccionado en un espacio y tiempo estancos, memorialístico, como tendremos ocasión de ver. De hecho, el mismo trabajo de redacción de la monografía a partir de los diarios de campo no supone otra cosa que la delimitación (casi o metafóricamente territorial) de aquella experiencia de campo: de observación participante, un eufemismo metodológico. El antropólogo no es tanto, así, un "autor", como quiere Geertz. Más bien es un acción compleja de notaría exilar, exégeta custodio de una verdad narrada, y, sobre todo, re-clamada. Ahora bien, ¿cuál es la responsabilidad del notario, que es distinta de la del autor? No sólo porque conforma, esta vez como autor, ese mundo de realidades suyas, pero designadas merced a su autoridad de emisión/certificación/notificación de realidades. Las ciencias sociales, así, localizan y globalizan el mundo. Pero, además, dejan fuera, en esa labor, otros mundos, no suyos, si bien previamente han desertizado (casi diríamos colonialmente) el territorio que debe quedar tras ella después de su labor de notaría. Se trata, por tanto, de "geopolíticas del conocimiento" (Mignolo, 2003). Ahora bien, el mundo por escrito etnográfico es asimismo reinterpretable, con lo que caben en él, no sólo la panoplia de todos los mundos posibles (socioetnográficos, escriturables), sino, en verdad, "todos los mundos" de la interpretación y la reinterpretación, y aún de la ficción, en encadenamientos correlativos. El sentido de la escritura como institución de violencia (Lévi-Strauss, 1970: Séptima Parte, cap. XXVIII) recae así en la imagen de la Biblioteca como receptáculo del conocimiento mundano y su esencia intrínseca como referente externo desde el que situar y resituar toda nueva "cultura" o "sociedad" escrita en anaqueles perfectamente clasificados por materias, autores 
y épocas ( $c f r$. Burke, 2002). La escritura cobra así una entidad en sí misma, en cuanto recurso de poder cognitivo absoluto y designativo, "metaforicidad en sí misma", como quiere Derrida (1998: 22). La metáfora de la Biblioteca del Mundo, la Naturaleza como Libro escrito en caracteres matemáticos, el mundo como manuscrito, la legibilidad del mundo, la lectura universal, etc. (Derrida, 1998: 22 ss.; Blumenberg, 2000; Olson, 1998), puede ser escindida en dos sentidos: fundada en patrones gramatológicos y técnicos; así como "pneumatológicos" o escritura indeleble en el alma (Derrida, 1998: 24). La escritura interna, esta escritura santificada, no es menos ajena a la labor escritural etnográfica que la primera. La Etnografía tiene el mismo sentido derridiano (Goldschmit, 2004). Los diarios íntimos publicados de Malinoswki, Eliade, etc., lo corroboran. Pero puesto que toda idea y sentimiento acaba por (ser) escrito y no deja de ser un ejercicio escritural en tanto sea comunicativo y lo es siempre ${ }^{22}$, y en cuanto, además, no deja de ser instituido como un acto de violencia ${ }^{23}$, en tanto todo esto tenga lugar (y pasa), su versión escrita la enaltece como autoridad (agente y, no lo olvidemos, beneficiario, de la violencia):

La idea del libro es la idea de una totalidad, finita o infinita, del significante; esta totalidad del significante no puede ser lo que es, una totalidad, salvo si una totalidad del significado constituida le preexiste, vigila su inscripción y sus signos, y es independiente de ella en su idealidad. La idea del libro, que remite siempre a una totalidad natural, es profundamente extraña al sentido de la escritura. Es la defensa enciclopédica de la teología y del logocentrismo contra la irrupción destructora de la escritura, contra su energía aforística, y... contra la diferencia en general. Si distinguimos el texto del libro, diremos que la destrucción del libro, tal como se anuncia actualmente en todos los dominios, descubre la superficie del texto. Esta violencia necesaria responde a una violencia que no fue menos necesaria (Derrida, 1998: 25).

22 En diálogo demoníaco, místico, con un alter ego, doble o sombra, que nos habla internamente, sea la conciencia bicameral, el démon socrático, la demencia, etc. La pertinencia de esta disquisición está en lo que adelantamos antes: La categoría exilar es el escribano de un sujeto encendido; un notario que acalla la voz por medio de la escritura. Es decir, más acá y más allá de la escritura y su imperio reside el sujeto que obra, actúa (de ahí que lo llamemos "encendido"), pero que habla y escribe (acallando ésta a la primera), incluso o precisamente su propia subjetividad (fijada, construida). El sujeto se escapa momentáneamente al texto. La cosa estudiada (objeto) necesita así un segundo autor (después del primero que se describe a sí mismo estudiando la cosa). De ahí la transterralidad, la transposición correlativa autorial o los encadenamientos de autores sucesivos y recurrentes, factum de la reflexibilidad en la expansividad del yo experiencial-escriturario.

23 En cuanto violenta la realidad y la verdad, a su vez escritas: de ahí la necesidad de reconocer esa metaforización en sí misma de la escritura derridiana. 
La diversidad queda clausurada. De esta asunción se deriva la pregunta que, si lo es filosóficamente, no es menos pertinente etnográficamente: el ser escrito, el qué es lo que está escrito, la voz y el fenómeno, lo dicho para lo oído o lo dicho para ser oído (Derrida, 1998: I, §3). En otras palabras, la pregunta etnográfica por la existencia de los mundos que describe, ante la duda de que existan autónomamente respecto de la escritura ${ }^{24} \mathrm{y}$, sobre todo, ante la inquietante constatación de que la escritura etnográfica abarca todos los mundos; o mejor, donde en su único libro se contempla o leen todos los mundos, muchos de ellos de vastedades insospechadas o aun silenciadas. La extraña sensación de que el escritor (etnógrafo) que dejó escrito o por escrito el mundo (etnográfico) que dice contempló en el pasa$\mathrm{do}^{25}$, experimenta dificultades de comprensión en la que fue su propia escritura, le lleva a enfrentarse a ella como a un otro (a él mismo como escritor-autor en otro tiempo, primera alteridad), ejerciendo una violencia recursiva para comprender por la fuerza un mundo ya motorizado en su ausencia, y adentrarse en la espesura de su trabajo escritural reflexivo. El texto viejo se presenta así, metafóricamente de nuevo bajo el poder de nuestra palanca cognitiva, como una espesura clásica (la floresta), donde el etnógrafo interroga al etnógrafo que fuera y lo violenta inquisitorialmente como si de un nativo se tratase, agitando el texto por el texto.

Los diarios de campo: el conocimiento que se abre al mundo escritural

Será menester ahora, con esta luz, describir nuestros diarios de campo. Se usaron cuatro libretas de distinto formato, conforme a un primer criterio clásico de separación o disgregación dualista "persona/investigador-observando participativamente (en el trabajo de) campo"; es decir: "intimidad, emocionalidad, subjetividad" disciplinada o socializada conforme al método académico ("trabajo de investigación, método científico, rol profesional y mérito académico”). En efecto, fueron estos:

a. Diario personal: se usó como diario íntimo, en el que recoger las emociones y secretos íntimos del investigador en el campo: se entendió como "campo" toda la "ficción" completa: esto es, "Colombia", la experiencia de viaje, como "campo". Esta libreta, de principio, como cuaderno aún vacío (sin escritura), fue escogido para tal fin por motivos afines muy claros: fue obsequiada por una persona afectivamen-

24 Y por tanto de la experiencia única de lo dicho para ser oído, así, por ejemplo, en Tristes Trópicos.

25 Cuando relee sus diarios de campo o su monografía y lo que dejó fuera como texto muerto, por silenciado, es decir, por escribir, y aun no escrito. 
te significativa, una compañera de trabajo en España antes de partir el investigador hacia el itinerario colombiano. La libreta está magníficamente encuadernada y presentada, a la moda de las libretas "ecológicas" (papel reciclado, anillas dobles metálicas, tela cosida, grabados coloreados). En la portada se lee en bajorrelieve sobre tela: "Nature Is Beautiful" y, debajo: "Fruits of the World". Se representan en altorrelieve coloreado de amarillo unas espigas de cereal, y abajo a un lado, en bajorrelieve el logotipo de la editorial: un cubo de basura con flores que salen de él. Cuelgan de las anillas unas etiquetas de cartón en las que además de este logo y su lema, que no reproducimos, se lee: "Is it trash?". Ignoramos si hubo en este regalo "ecológico" una clara intencionalidad en relación con un viaje de aventura a un lugar que destaca desde el prejuicio cognitivo eurocéntrico, entre otras cosas, por su exuberancia natural. Aunque es más que posible establecer esta relación, albergamos aún alguna duda por cuanto en esta época, tales obsequios estaban "a la moda" de esta pretendida conciencia europea por "la protección del medio ambiente". Sea como fuere, lo uno (esta consciencia) está en relación con lo otro: con la conservación en zonas de abundancia forestal, por ejemplo; qué duda cabe que la Amazonía constituye así un "mito contemporáneo" que, al mismo tiempo que se desea conservar, se visita turísticamente como lugar de aventura y, por ende, de consumo "de los orígenes".

Después de que detrás de la portada el investigador inscribiera su marca de propiedad (apropiación previa de lo que vendrá) y un aviso para que, en caso de extravío, la libreta fuera depositada en la universidad colombiana de acogida, la primera página recoge una dedicatoria de la compañera que le regaló el cuaderno: "Verano-98. Una parte de tu sueño se está haciendo realidad y comparto tu alegría. Ahora estarás más cerca del secreto de la vida. Comparte con nosotros, a la vuelta, tu experiencia. Buena suerte. Un abrazo. [Firma]" (Diario personal, p. 1). No podemos dejar pasar que al viviseccionar estas circunstancias "personales o íntimas", y, sobre todo, al desvelar esta dedicatoria (que sólo fue escrita, sin mayores suposiciones, para el consumo exclusivo del propietario de la libreta), estamos violando el secreto de la intimidad, ejerciendo pública violencia escritural con ello. La distancia y el desapasionamiento que hoy nos permite hacerlo, más allá de vanidades o exhibiciones analíticas, permiten hacer patente, de cualquier forma, 
esta forma de violencia escritural que no se da solo en el campo, sino antes y a propósito en la construcción de la subjetividad del investigador: que des-vela o avienta la interioridad de algo que, por otra parte, es menester estudiar al ser parte integrante de las circunstancias de la investigación. El contenido de esta "bendición fraternal", si no amorosa como margarita de guerra (novia o promesa que espera el retorno del soldado), unida a la espiritualidad intelectual del "estar más cerca del secreto de la vida", por experiencia y conocimiento, es claramente "vincular" y, por tanto, afectivo. Se espera y pide la "vuelta", un regreso. Lo que prometería el autor, por cierto, en cartas postales posteriores. Esto es la garantía de la ida a aquél lugar inhóspito y de colonización exigente: una aventura, en todo caso, de inteligibilidad intelectual con sufrimiento emocional (ese altavoz de la prueba testimonial).

El diario tiene 76 páginas escritas, desde la llegada a Medellín (3 de agosto de 1998) hasta el viaje a Apartadó (14 de septiembre), en que se interrumpe sin aclaraciones ${ }^{26}$. Además de gráficos y esquemas ${ }^{27}$, contiene también algunos dibujos a bolígrafo y uno hecho con la tintura de hierbas locales. Éstos son paisajes, pero también la representación de la reducción de una cabeza (de supuesta procedencia jíbara) de uso medicinal en las plazas de Medellín. El contenido del diario, como adelantamos, recoge cuestiones que también se constituyen como "personales", sobre todo en cuanto problemas de conocimiento: reflexiones epistemológicas relativas al conocimiento de la situación sociocultural de un país ajeno, sobre el urbanismo de Medellín ante las dificultades de orientación...; y que, en lo estrictamente emocional, dado su traslado hacia lo cognitivo, fueron encarnándose rápidamente en un malestar gástrico. Todo lo cual, evidentemente, cuestiona de raíz la dificultad e impertinencia metodológica de esta separación dual entre la subjetividad a salvo (acantonada por escrito

26 Probablemente debido al cansancio. Y al decir esto, nos encontramos con una asunción que sacia nuestro vacío o ignorancia (o angustia y culpabilidad por no conocer qué hicimos o el porqué de nuestras conductas y decisiones), puesto que, evidentemente, no recordamos o sabemos por qué se interrumpe ahí, siendo que la estancia en Colombia continuó. Se trata pues de una nueva violencia escritural (la del silencio), que se ejerce incluso sobre nuestra persona en situación, en el campo, como personaje (sujeto de nuestras averiguaciones) $\mathrm{u}$ otredad en ciernes.

27 Muchos de ellos, sorprendentemente en este diario, analíticos de la situación sociopolítica del país, cuestiones epistemológicas, urbanísticas, etc. Al parecer, la presencia emocional se transmutaba en cognición. 
en un Diario personal) o a raya, contenida por escrito, que dejará expedito el trabajo escritural (científico, incontaminado) en el campo.

b. Diarios de campo 'strictu sensu': consta de dos cuadernos, comprados sucesivamente uno detrás de otro, y ya en los lugares de paso y necesidad (escritural) en Colombia. Mientras el primer diario (el que llamamos personal) está bien cuidado o conservado, éstos otros de campo están maltrechos, manoseados y acusan el desgaste en el campo ${ }^{28}$, marcas que le confieren la autoridad de una vejez curtida. Concretamente, sus hojas se inundaron de la humedad del trópico y, con la tinta corrida, contienen abultados anexos que los deforman y deslucen: folletos, hojas anexas, recortes de prensa, etc., recopilados en el campo; fueron transportados en mochilas y zurrones, a través de distintos medios. Los cuadernos son baratos, ordinarios, con anillas dobles a la izquierda y tapas de cartón con estampados gráficos a color de máquinas de escribir antiguas, por cierto, y desiertos indeterminados. Las páginas están cuadriculadas en el segundo, y rayadas en el primero. El Diario que llamaremos I comienza en "el campo" estrictamente (es decir, en el campo antropológico razón de la expedición académica al Chocó): nos sitúa en la Reserva de Sasardí el 28 de agosto; y acaba, con el cuaderno completo, en un Taller en Gilgal (sin fecha), tras 155 páginas. El Diario II siguiente comienza en el mismo taller de Gilgal (continuación) y tras 120 páginas acaba con la transcripción de una entrevista a una familia en Ríosucio ${ }^{29}$. Este último Diario está dotado con mucho más material de anexos, gráficos analíticos, mapas urbanos, dibujos de paisajes, etc. Por supuesto, ambos diarios mezclan, junto con las observaciones participantes, reflexiones analíticas variadas, comentarios bibliográficos, etc., de una manera bastante descuidada y confusa, que achacaremos al imberbe etnógrafo, por una parte, y a su abandono como documento, por otra: se trata de unos diarios sin trabajar, sin desbastar para servir al análisis; sin rotular las categorías analíticas en el margenado, ni volcar la información. La escritura es mucho más rápida y nerviosa, a veces sin apoyo firme. Como dijimos, estos diarios no tuvieron aplicación fruc-

28 El "personal" fue conservado en Medellín mientras duró el trabajo de campo en el Darién.

29 Si bien esto fue anterior y, en realidad, acaba en Bahía Solano, en el Pacífico, sin que conste la fecha, aunque coincide con el final de la expedición al Chocó. 
tífera, sirviendo más bien de iniciación etnográfica, cuestión que sería atendida en numerosas discusiones con sus compañeros antropólogos ${ }^{30}$.

c. Diario auxiliar de evaluación (de campo) de la intervención social de una ONG. europea: aunque no se adelantó, por motivos laborales, compatibilizando su beca de investigación, el autor se comprometió a girar una visita a las intervenciones en el Urabá que la ONG para la que trabajaba en España sostenía; en este viaje al Urabá antioqueño se llevó a efecto una evaluación, con metodología de campo, para la redacción de un informe técnico sobre la intervención social que lleva a cabo dicha institución en barrios de invasión en distintas poblaciones de la región. La libreta está adquirida en Apartadó, y es de apertura vertical, totalmente blanca. Consta de varias páginas escritas con datos de observación sistemática sobre las tareas, organización, etc., escolar, alimentaria, de atención psicológica, de capacitación de adultos y talleres, de construcción de viviendas, etc., que esta ONG auspicia y que ejecuta la contraparte colombiana. A partir de él se redactó un informe evaluativo presentado en España (y que, por cierto, no gustó nada, ni en sus conclusiones críticas y recomendaciones, ni en su metodología), muy de acorde con la investigación de campo anterior: los dos estudios están mucho más que relacionados y son de una referencia cruzada interesante, con lo cual volvemos a recordar la pregunta por la motorización del objeto.

d. Otros materiales: que consideramos actúan como documentación anexa y complementaria, como es la prensa colombiana, grabaciones de audio en las entrevistas de campo (si bien éste es parte integrante, en cuanto sea transcrito, de los Diarios de campo), estadísticas, libros, folletos publicitarios, visionados de documentales, noticiarios y programas, radio, etc. Resulta interesante constatar la dificultad, la ajenidad temporal y situacional, de entender estas grabaciones, giros idiomáticos, circunstancias biográficas de los entrevistados, etc., mucho tiempo después de realizadas. Por cierto, que hubimos de sobornar a varios desplazados en el Coliseo de Turbo para obtener información, con lo

30 No obstante, estos diarios sí dieron lugar, al menos en parte y como experiencia de base y conocimiento local de principio, para redactar el ensayo "El corazón lejos de la boca. Contribución al estudio, en los diferentes grupos humanos del Darién, de las concepciones corporales en relación con su naturaleza", firmado por el autor, más a partir de la recopilación y crítica de las fuentes bibliográficas pertinentes estudiadas por él en la investigación bibliográfica en la Universidad de Antioquia, Medellín, y que constituyó parte de la obra de conjunto "El Darién. Ocupación, poblamiento y transformaciones ambientales" (2 vols.). 
que volvemos a la motorización, amén de los escrúpulos éticos y las consecuencias para la veracidad de la información así producida.

De todos estos materiales, diarios, etc., vemos cómo surgen, en su "lectura de hoy y desde acá", transpuesta la distancia, un extrañamiento; cuya violencia no se resuelve sino escrituralmente, que atribuimos a las siguientes características o condiciones:

1. Distancia temporal y geográfica, así como situacional. Temporo-espacial: estudio de una supuesta "realidad colombiana" desde España y en nuestra circunstancia actual, que no deja de ser concatenante y recursiva: aquella experiencia nos trajo aquí y nos ha movido. Es precisamente este decir, desde España, la declaración de este ángulo de mira u oquedad; el que, precisamente, define aquella "realidad colombiana" o, mejor aún, define la realidad de Colombia, de una Colombia que por esa misma distancia general (espaciotemporal y exótica) es ajena hoy tanto como ayer, de otra forma "no mía" pero extrañada. El acto de conocimiento, de análisis sobre ese objeto, requiere pues una aprehensión, una apropiación, un hacer mía aquella (esa) Colombia, a la cual, para lograr esto, necesito añadir cosas mías, lo que uno aporta como investigador o persona cognoscente: lo que la hace real, la "realidad" (que es mía, puesta por mí, en mi acto de investigación), la colombianidad o colombianía mía que así la designa: de ahí que en discusiones simpáticas diga yo frente a conocidos y amigos bogotanos que soy pai$s a$-de Antioquia-; y que es refrendada por mi compañero de intercambio y colaboración J. D. Gómez Quintero, aquí en España, junto a mí como alter disciplinario (sociólogo) y transterrado (colombiano radicado en España) de mirada recíproca: al fin y al cabo, colombiano que refrenda la existencia y $m i$ estancia fraternal en Colombia.

2. Ajenidad en la comprensión: evidentemente, son las audiciones actuales del material de audio grabado en Colombia lo que más ajeno resulta; sobre todo por la dificultad de la comprensión de la dicción y el acento; ajenidad por la dificultad en la comprensión del acento del agente hablante (oralidad); y ajenidad por las dificultades de audición debidas a problemas técnicos e instrumentales. El diario "acerca" estos casos. Los folletos, periódicos, etc., material escrito "por otros" e institucionaliza- 
do por las prensas-instrumentos de edición y fuentes de enunciación, requieren un esfuerzo distinto: de comprensión "por la letra/lectura".

3. Ajenidad de la escritura: los Diarios y demás material escrito o producido personalmente exige un esfuerzo doble: de comprensión de la misma letra nuestra (inteligibilidad); y de comprensión de su contenido, del referente cultural y sociopolítico, de la entidad territorial y nacional, de lo local constatado y experimentado. Y de la subjetividad situada y en ciernes: la nuestra, que se nos escapa sin sentir, aunque permanece encendida.

4. Todo esto supone una ajenidad de principio: la dada en el campo por la misma situación exigida en la práctica de investigación, siempre asimétrica en el sentido visitador/visitado, entrevistador/entrevistado, asesor/ asesorado, investigador/informante, etc. Una ajenidad que es bidireccional: ¿qué pequeña investigación/ajenidad no emprenderá o sentirá el investigado-entrevistado frente a quien le pregunta, recorriendo éste, incluso, miles de kilómetros en pos de quien responde a su entrevista, esa estrepitosa búsqueda del informante cualificado de la que dimos cuenta?

\section{El libro de todos los mundos o la doble ajenidad del mundo por escrito}

Los Diarios y demás materiales, como ficticios hitos testimoniales, colonizan el campo. Los Diarios de campo (I y II) ponen una primera limitación y concentran o re-concentran el campo: el primer campo, o lo que así se consideró como tal fue, dentro de Colombia, el último círculo concéntrico posible: la expedición antropológica al Chocó (al Darién). Sin embargo, los materiales adyacentes y el propio viaje posterior a las estribaciones del Chocó, el Urabá antioqueño (complemento pero contrapunto del Chocó: del Urabá chocoano), y con otro objeto de estudio asimismo adyacente (las ONG), hacen que este círculo, con otro centro o desplazamiento de centro, se resquebraje y concierna a otros, en una mirada hacia afuera que deconstruye la primitiva disposición de la iniciación antropológica en un campo que ahora se advierte más difuso: de adentro afuera. En efecto, no solo constatamos dos campos restringidos: el Chocó y el Urabá antioqueño; el binomio analítico salud/enfermedad en el primero e intervenciones de ONG en el segundo que, por supuesto, acoge la cuestión sanitaria; sino que el primer objeto de estudio, perfilado desde España a 
demanda de la beca propuesta desde Medellín ${ }^{31}$, había sido la juventud en los barrios de invasión, las comunas de Medellín. Así pues, otro círculo concéntrico hacia fuera, centrífugo. Finalmente, Colombia como tal, en su totalidad, pergeñada desde la predisposición construida en y desde España; sin conocimiento experiencial de qué sea "Colombia".

El Diario personal nos sirve para recordar que nuestra entrada o inmersión, como se prefiera, en el campo mayor (Colombia), es poco consistente en su contenido, puesto que nos re-situamos o nos vemos obligados a resituarnos, orientándonos de manera correlativa (fenómeno de localización y deslocalización/transterralización), desde luego cognitivamente: "Una vez instalado en casa de la familia Gómez... conocí la Universidad [y a la familia, que se definen como situados en cierto estrato social]. Tiene esto importancia, aunque lo comprendí más tarde, porque en Medellín, la ciudad cobra sentido humano en lo espacial, en la ubicación urbana" (Diario personal, p. 2). Es decir, el Diario que primero se escribe (y que primero se abandona, por cierto), el supuestamente "personal", puesto que fue lo personal lo primero que se vio comprometido llevado por el temor a lo desconocido o el terror conocido, por construido, desde España, es aquél que sirve para el conocimiento: la resituación primera, que siempre es cognitiva por escritural. Evidentemente, entendemos que lo afectivo es una performatividad colonizadora también, en el ámbito de la escena relacional e imaginaria; pero que deviene escritural también como afectación de la escritura, como gesto, cara a medios más netamente literarios y artísticos, donde la ficción y lo poético rebaten la idea prosaica de lo cognitivo; no obstante, desde la crítica, ambos ámbitos se inmiscuyen y confunden mutuamente, claro está. Y si hablamos de resituación o ubicación (cognitiva) es porque, como se ha visto, allí se le presta un instrumento conocido: la metáfora del mapa urbano y la significación (social, estratificada) de lo espacial como señal identitaria. Por supuesto, esta herramienta de comprensión es compartida inter-nacionalmente por el mero hecho de que ambos interlocutores estaban muy próximos una educación universitaria, socializados en las ciencias sociales: uno antropólogo; el otro sociólogo; y a ciencia cierta con anhelos, situaciones sociopersonales, etc., muy similares. Es decir, la globalización ha hecho que estos dos ahora amigos se entendiesen sin dificultad en aquella primera situación donde

31 Aclaremos que la estancia del antropólogo en la U. de Antioquia se debió a una beca de la AECI, España, que en principio demandó un proyecto para una universidad privada de Medellín, tratándose de un error administrativo que fue subsanado con el traslado a la U. de Antioquia (ver infra). 
uno demandaba explicaciones/entendimientos y el otro las proporcionaba gustoso como símbolo de conciliación y hospitalidad, así como de intercambio intelectual. Es más, sería el antropólogo español quien se resistiera a aceptar la violencia como uno de los criterios asiduos y precisos de explicar qué cosa es "Colombia" para un extranjero. Nos referimos a la muy comentada anécdota de una discusión en el carro de los amigos de Juan David cuando mostraron al español el Cerro Nutibara y las vistas de Medellín, etc., en cuyo transcurso los amigos colombianos se lamentaban de "la violencia" como algo que preside la vida de Colombia, lo que el primero se resistía a aceptar, dándola, con afectada suficiencia, por supuesta: paradójicamente como si supiera qué significa la violencia en Colombia o si la hubiera experimentado en propia carne. Es decir, la mera presencia del extranjero (más si cabe "estudiante") ${ }^{32}$, exige explicaciones ( $\sin$ necesidad de entrevistas), y un esfuerzo por mostrar qué cosas de qué "Colombia"; o qué cosas identifican a "una Colombia" que uno desea estudiar.

Así pues, el Diario personal, lejos de proteger lo personal o mantenerlo en cuarentena para la no contaminación de los Diarios de campo, pasa a ampliar el campo a toda la experiencia, a todo el país como lugar de experiencia; es decir, abre a la experiencia, a lo experiencial, el campo antes restringido. Y lo hace por escrito. De hecho, el Diario personal actúa como Diario de campo, de un campo más abierto, de "Colombia" (en construcción y en itinerario) como campo, y hasta recoge, además de resituaciones cognitivas (la estratificación, entre otras), reflexiones de método general (Diario personal, pp. 19 y 20). Aquí se recogen las "realidades" explicando los deslindes de los "acontecimientos"; un entronque de teorías, puestas en cuarentena por la experiencia personal, que rectifica unas y suma otras no tan empíricamente, sino reflexivamente en ese concatenamiento escritural. Los acontecimientos se deslindan así en una elec-

32 La condición de "extranjero" gira en torno a varios criterios de visibilidad: 1. El prejuicio atribuido a la costumbre: el europeo que apenas se ducha, como le fue recordado en alguna ocasión; a lo que responderemos, además de con los insanos hábitos europeos, con las precauciones de claro interés simbólico dadas por la Embajada de España de no bañase en pozas por el riesgo de parasitismo; 2. El "tener cara de extranjero" (Diario personal, p. 13), lo que lo hace víctima deseable para el secuestro o el robo: no sólo en la advertencia/preocupación de la familia de acogida; sino asimismo en la Universidad en la expedición al Darién, donde se le recordó que no podía garantizarse su seguridad y se le impelió a que disimulara en lo posible su acento (español) intercalando muchos "pues" y otros colombianismos; además, sobre todo en relación al cambio de dinero, siempre le fue facilitado por intermediarios colombianos: en el traslado de dinero de un banco, que fue hecha por un compañero de universidad; en el canje callejero de dólares por pesos; o en las incursiones por barrios de invasión, en las que precisa cierta "proxémica" que uno, como extranjero, no posee, etc. 
ción crítica personal, permitida, facilitada, contrariada o perseguida por la convención social o colectiva a través de sus muchas instituciones (familia, etc.) y ocasiones (rituales de encuentro, etc.) en las que se pone en cuarentena la subjetividad y el objeto. Los epígrafes escritos o los temas tratados no son otra cosa que glosas del acontecimiento escrito y, por tanto, por escrito, violentado en mucho aquél objeto y aquella subjetividad apriorísticas. Por ende, sí hay un margenado de los diarios, al hilo de la propia reflexibilidad escritural. El acontecimiento es reconocido así, como tal, como "acontecimiento", "hecho de un acontecer o acontecido" en cuanto ha sido deslindado de otro "acontecimiento consiguiente o antecedente": lo que significa que éstos son impulsados y llevan inercia unos con otros en cuanto a su "registro" y "relevancia". Este registro o conteo mecanizado-subjetivizado proporciona al sujeto/observador un rosario, una muestra de continuidad donde entresacar, en la operación de deslinde (relevancia), "acontecimientos" glosados. Se trata, por tanto, de una teoría temporal precisa para la teorización antropológica. Esto, por último, permite entender el objeto como motorizado, móvil, impulsado por la acción misma criterial del observador, y no sólo por su observación o en su observación.

Poniendo ejemplos concretos, podemos ver los trasvases de sentido. La premisa analítica deslindada que en nuestro ejemplo primero fue la "estratificación" social en Medellín (argumento A); toda vez que haya sido aclarada, sirve de guion para el conocimiento más riguroso de la "realidad" colombiana, que no es otro que la designada por o como "la violencia". Lo que glosa o deslinda, y explica, los acontecimientos vivenciales concretos a ese argumento, por ejemplo, como podemos ver en los extractos:

[Ya en la Universidad:] Mi tutor, proveniente de la zona 2 (Santa Cruz)..., [me traslada de universidad -de la privada a la pública, a causa del error en la beca- $\mathrm{y}$ me inscribe en el departamento de Antropología de la Universidad de Antioquia. Con los profesores de esta universidad me explica la estratificación a que obedece la universidad privada, etc. $]^{33}$ Me cuenta en la biblioteca, no sin el misterio de la iniciación la "realidad" colombiana. [Que se compone de preguntas como:] ¿De quién es este muerto? ¿Quién mató a X? La muerte del joven es incertidumbre súbita. [Pinta un ataúd en la libreta.] (Diario personal, p. 5).

33 Aquí se "explica", glosa, por ejemplo, el acontecimiento vivencial 1, que podría ser, en torno a lo vivido en la universidad privada, cualquier de las anécdotas experimentadas (la facilidad de acceso y el abuso de la cirugía estética en el alumnado de la universidad privada, $e$. gr., una marca de estratificación socioeconómica, evidentemente). 
Con posterioridad a esta circunstancia, unida a la construida desde España, el Diario personal irá acogiendo la evolución del malestar gástrico del autor, en torno al miedo. Lo que requerirá incluso la asistencia al médico de la universidad y un tratamiento puntual en forma de psicoterapia de consulta: pensabas que los muertos caerían en Medellín a tu derecha y a tu izquierda; pero no caen a ninguno de los dos lados. La "realidad" es otra. En el mismo sentido, este Diario recoge las cavilaciones en torno al objeto de estudio, en cuanto a la conjugación que debe hacer a raíz de los compromisos adquiridos con su empresa laboral: lo que resultará en el viaje al Urabá antioqueño para la evaluación de la intervención de la ONG española; sus universidades (de emisión y recepción); y la institución promotora de la beca. Poco después, las primeras consideraciones son expresadas de manera muy concreta:

Entre el Dengue hemorrágico y el carro bomba transcurrieron los noticiarios de los últimos días. Anteanoche se escuchó una deflagración [en Medellín] y dijeron: "Una bomba". En efecto. En Mutatá hubo muertes también. La muerte puede ser súbita, pero la sensación de que nos ronda, la persecución (paranoia) es más intensa aquí en Colombia. Entre el dengue hemorrágico y el baleo [balacera] o coche bomba (causa natural y social de muerte), el campesino, como el ciudadano [colombianos, según expresiones populares, en relación al primero más que al segundo], como el colombiano al fin, "están jodidos". Frente al "se nace pa'vivir", el "no nacimos pa'semilla" (Diario personal, p. 11)

Por lo que continúa:

Debo fijarme en cómo me adoctrinan sobre lo colombiano, en torno a la violencia... [Compruebo que aunque mi tutor] hace que cambie de universidad, la de Antioquia, [donde aparecen por la noche, de vez en cuando] encapuchados [armados, gritando consignas políticas; y los profesores de la Universidad de Antioquia critican el estatus de la universidad anterior; es en realidad en aquella universidad privada donde asisto a fuertes debates, aun de manera informal] sobre la historia colombiana, guerrilla, Tirofijo delincuente... No queda clara la diferencia entre Terrorismo español y guerrilla colombiana (Diario personal, p. 11).

Como es obvio, la experiencia de la violencia ejercida contra el estudiante se iría aproximando paulatinamente, más si cabe en el Chocó y el Urabá an-

34 En la página 12 se anota la expresión que le diera su tutor en esta iniciación: "La realidad colombiana del 'campesino está jodido', 'pero también en la ciudad lo estamos"”. 
tioqueño: "En la Universidad de Antioquia leo un cartel delante de un policía que intimida con un enorme braco. El cartel a tiza denuncia el robo de un carro a punta de cuchillo, y habla de 'esta ciudad donde es cosa habitual despojar a uno de lo que tiene"” (Diario personal, p. 13). Y así, se ve afectado por semejante persecución:

Sigo nervioso, o más bien inquieto, estresado, sudoroso, con el ánimo de quien espera morir de súbito, inesperada o inadvertidamente. El hecho de ser y parecer extranjero..., añade agudeza y mantiene permanente -como lo es mi condición- esta sensación del perseguido, del que se sabe despojado próximamente, en cualquier momento. Parece como si, en cierto modo, lo deseara o esperase, o fuese común, algo debido al azar que me toca (Diario personal, p.14).

Sin embargo, este padecimiento del extranjero es una pose, una aventura, una experiencia de cálculo, un exotismo carnal, dado que él está, paradójicamente, mucho más seguro que cualquier colombiano sin recursos de seguridad. Qué duda cabe que la violencia, en todas sus formas, es un fenómeno estructural y que incumbe no sólo a las sociedades globalizadas, sino al modo de producir y reproducir conocimiento, lo que más nos importa aquí (Jaramillo Marín, s. f.); que se hace físico en nuestro caso merced a las presiones sociales que se experimentaron para su supuesta autoprotección: una socialización en la violencia, aun en sentido negativo, sin sufrir otra cosa que la encarnación de la ficción del "riesgo" o el estrechamiento de la "seguridad". La comparación a que dará lugar el terrorismo en España con respecto al experimentado en Colombia (así en diversas comparaciones desde España o en Colombia), las advertencias de la Embajada española, los cuidados de la familia y la universidad de acogida; las precauciones sobre los colombianos y los paisas; las experiencias en el campo, en fin, lo certifican. De la misma manera que nuestro compañero experimentará emociones desabridas y conflictivas en España ante la supuesta y autoatribuida representatividad de lo colombiano o la situación de Colombia por parte de colectivos de apoyo a organizaciones subversivas en Colombia presentes en eventos públicos, culturales y festividades; o su comprensión-incomprensión del terrorismo en España; o su condición migrante.

Pero nos importa cómo la violencia se recrea y ejerce escrituralmente, al hilo de nuestra reflexión epistemo- y metodológica y en el transcurso de una socialización ingenua que desvela la asimetría de los que aquí vienen y los que allí van. Con nuestra presencia e intencionalidad en el campo, como señalamos. 
Porque el campo "Colombia" se nutre del imaginario previo "Colombia violenta"; y porque de la salud se pasa a la política. Así, uno de los temas recurrentes será el de la implantación y evaluación del "desarrollo" local, de pretensión nacional y global, donde entraba a formar parte la preocupación por la salud. En este orden, una de las preocupaciones/intenciones que declaramos en nuestro trabajo tocaba a la ordenación del territorio para su mejor gestión estatal y la labor de ONG. Nuestros diarios, en fin, atravesarán itinerarios internos en los que se pasará más o menos imperceptiblemente (como corrientes y deslizamientos subterráneos) por distintos momentos de única concentración sobre el objeto (la sanidad en el Chocó), y de máximo abandono del mismo (la política a tenor de la planificación territorial) $)^{35}$.

\section{A modo de conclusión confesa: La propulsión o motorización del objeto, tan escasa}

Es evidente, así lo querríamos, que en nuestra actitud indagatoria propulsamos o pusimos motor al objeto de estudio: e. gr., la ayuda a líderes locales en la ordenación territorial; de lo cual, por cierto, perdimos noticia. Pero, es tan poco...; o tan vano... ${ }^{36}$ Porque, mover, movemos otras cosas. Con estos movimientos, nos motorizamos nosotros por trayectorias calculadas. Nos impulsamos por medio de su palanca en la promoción como investigadores y en el mundo académico; en el plano íntimo, siquiera como enriquecimiento iniciático, tan caro al afán europeo; en el social en definitiva, con réditos claros, a menudo sociopolíticos y de prestigio, en nuestro entorno cotidiano. Pero, ¿cuál es ese motor doble? La violencia de la escritura. Motorizamos, fundamentalmente, identidades y procesos sociales más o menos difusos, catalizamos cuestiones de género (actuamos como autoridad), pero también, desmotorizamos, ralentizamos, frenamos, partimos el motor, etc. En muchas ocasiones, quizá la

35 Hay que pensar que el grupo de investigadores al Chocó, en el cual se incrustó el autor, mencionó varias veces la peligrosidad de la documentación que iba acumulando (incluidas fotografías, por ejemplo de potrerización de la selva), y que en varias ocasiones, lo que no es ilícito pero no creemos que estuviera sistematizado, se ayudó explícitamente a líderes afrocolombianas en la preparación de la defensa zonal en la planificación territorial. Un mayor compromiso metodológico estaría a nuestro juicio en adquirir metodologías de Investigación-Acción-Participación.

36 Tanto en nuestras investigaciones posteriores en el Gran Chaco como en Ecuador sobre políticas públicas, los grupos con los que trabajamos nos hacían peticiones constantes, mencionando la extracción de datos y la poca o nula repercusión de estas indagaciones en la mejora de sus vidas. 
mayoría, no podemos ser tan arrogantes, ni tan pesimistas, pues ni movemos ni retardamos nada. No nos vamos a condenar calculadamente. Esperaremos, con sinceridad de muerte, a que otros nos condenen. Glorificación. La escritura, violenta transcendental. Porque podemos pensar, en nuestro caso, que recogemos, del cajón, una pequeña colección de diarios abandonados. En realidad, un trofeo eurocéntrico de guerra, de la colonialidad del saber, aunque lo consideremos humilde, casi un juego, una miniaturización del recuerdo neocolonial; una recreación histórica; una vieja estampa familiar. Se produce entonces la relectura de café, en la confortabilidad de las pequeñas historias del espacio doméstico extendido hasta las vastedades de la experiencia selvática. Un exotismo de cajetín de recuerdos. Acontece entonces la relectura autoral, como una sorpresa: donde la ajenidad nos enfrenta a una alteridad no indígena, sino en espejo de quien esto escribió en otro tiempo remoto. El lugar lejano se torna aquí en tiempo remoto. Se pierden por el camino las alteridades que pueblan estos cuadernos, y sólo queda la indianidad de quien esto escribiera. El paisaje despoblado se torna en la alteridad histórica. El romanticismo de esta escena no es pacífico, de todas formas. Es preciso mantener, defender, la ininteligibilidad de esos textos. Esto es lo que hacemos. Sostenerlos en el exotismo. Vivimos de eso, nos concede la identidad, incluso profesional. Aun así, y por ello, lo hacemos con sistema: ejercemos violencia al abrir nuestra cajita de recuerdos como si la tolerancia del trofeo del asesino necesitara más repetición en la frecuencia, o nuevos objetos. Ejercemos violencia contra la alteridad del objeto, en la herida de placer del sujeto-autor-otro, anidando ambos en la ininteligibilidad. Nos desconocemos aquí porque queremos estar allí permanentemente, sin regresar tanto. La alteridad escrituraria es una máquina que sigue escribiendo, y porfía. Nos sitúa de nuevo en un tiempo exilar, que se reescribe tantas veces. Crea un mundo repetido. Abrir cada libreta es activar el dispositivo creativo, rememorativo. Aparece en él el mundo escriturado. Lo leemos con placer, con el placer de la incomprensión. Después lo volvemos abandonar en una economía del olvido recuperable. ¿Es por esto que decimos que se mueve?

Sin embargo, apenas podemos calibrar estas velocidades. Esta cuestión, en fin, concluyendo, queda aquí sólo perfilada, y exige consideraciones que merecen mayores debates. Especialmente, siendo una confesión. 


\section{Bibliografía}

Bartra, Roger

1996 El salvaje en el espejo. Barcelona: Destino.

Blumenberg, Hans

2000 La legibilidad del mundo. Barcelona: Paidós.

Burke, Peter

2002 Historia social del conocimiento. De Gutenberg a Diderot. Barcelona: Paidós. Calavia Sáez, Oscar

2002 Extranjeros sin fronteras. Alteridad, nombre e historia entre los Yaminawa. Indiana, 19, 20: 73-88.

Castillejo Cuéllar, Alejandro

2009 Los archivos del dolor: ensayos sobre la violencia y el recuerdo en la Sudáfrica contemporánea. Bogotá: Universidad de los Andes.

De la Flor, F.R.

1999 La península metafísica. Arte, literatura y pensamiento en la España de la Contrarreforma. Madrid: Biblioteca Nueva.

Derrida, Jacques

1998 De la Gramatología, México: Siglo XXI. Traducción de Oscar del Barco y Conrado Ceretti, Parte II, "Naturaleza, cultura, escritura".

Escobar, Arturo

1996 La invención del Tercer Mundo, Construcción y deconstrucción del desarrollo. Bogotá: Grupo Editorial Norma.

1999 El final del salvaje. Naturaleza, cultura y política en la antropología contemporánea, Bogotá: ICAN, CEREC.

Goldschmit, M.

2004 Logocentrismo y etnología. Lévi-strauss. En: Jacques Derrida, una introducción (pp. 51-59). Buenos Aires: Nueva Visión.

Gómez Quintero, Juan David y Santiago Martínez Magdalena

2005a Cambio cultural y globalización: reflexiones en torno a América Latina. En: International Symposium on Sociology. Zaragoza, España.

2005b El libro de todas las repúblicas: a propósito de identidades, globalización y contraglobalización en América Latina. En: Ch. Marcuello y J. L. Fandos (Comp.), Aproximaciones sociológicas para una sociedad mundial (pp. 103121). Zaragoza: Ed. Simposio Internacional de Sociología y U. de Zaragoza. 
González Escobar, Luis Fernando

1999 El Darién. Ocupación, poblamiento y transformación ambiental: una revisión histórica. Medellín: CISH y F. Natura, y U. de Antioquia.

Hammersley, M., y Atkinson, P.

2003 Etnografía. Métodos de investigación. Barcelona: Paidós. Jaramillo Marín, J.

s. f. "Comisiones, expertos y diagnósticos sobre la guerra en Colombia: un ejercicio de economía política del diagnóstico. En: Actas del X Congreso Nacional de Sociología (pp. 381-398). Bogotá: ICESI.

Lévi-Strauss, C.

1988 Tristes trópicos. Barcelona: Paidós.

Martínez Magdalena, Santiago

Inédito Marco, escena y campo. Espacios y tiempos de sociabilidad experta en la ficción identitaria española. S. d.

1999 El corazón, lejos de la boca. Contribución al estudio, en los diferentes grupos humanos del Darién, de las concepciones corporales en relación con su naturaleza. En: El Darién. Ocupación, poblamiento y transformaciones ambientales, s. p., 2 vols., Medellín: U. de Antioquia-F. Darién-F. Natura.

2000 Tierra de Resurrección, navío de equívocos e ilusión cartográfica: ir allá desde aquí para volver aquí desde allá. Reflexiones acerca de una estancia académica en Colombia. Gazeta de Antropología, 16, http://www.ugr. es/ pwlac/G16_14Santiago_Martinez_Magdalena.html

2005 Consideraciones metodológicas sobre los informantes cualificados: un caso en la Etnografía, el Folklore y el costumbrismo regionales en España. En: I Congreso Internacional sobre Etnografía, Póvoa de Varzim, Portugal, 2005 (AGIR). Actas.

2006 Retales y quincalla: lances perdidos, lápices rotos, fracasos escondidos y cajón. Cuadernos. Revista de Humanidades, 4, UNED-Tudela de Navarra.

2007 Demoliciones para la ruina del conocimiento: una modernidad postapocalíptica. En: I Encuentro de jóvenes investigadores en torno al Mediterráneo. Tarragona. URV.

2013 Ocho páginas: un juguete moral con veinte miniaturas bélicas. Revista de Antropología experimental, 13, Texto 22, pp. 341-379.

2014 Campo ciego: la oclusión del último dominio etnográfico. Tramas. Subjetividad y procesos sociales, 39(22), 197-236. 
Martínez Magdalena, Santiago, y Juan David Gómez Quintero

2007 Imágenes del tercer mundo. Geografías y etnografías imaginarias en la representación simbólica de la conmiseración contemporánea. En: O. Calavia, J. C. Gimeno y M. E. Rodríguez (Ed.), Neoliberalismo, ONG y Pueblos indígenas en América Latina (pp. 81-106). Málaga: Sepha.

Menéndez, E.L.

2002 La parte negada de la cultura. Relativismo, diferencias y racismo. Barcelona: Bellaterra.

Mignolo, Walter D.

2003 Historias locales/diseños globales. Colonialidad, conocimientos subalternos y pensamiento fronterizo. Madrid: Akal.

2011 "Geopolítica de la sensibilidad y del conocimiento. Sobre (de)colonialidad, pensamiento fronterizo y desobediencia epistémica", http://eipcp.net/transversal $/ 0112 /$ mignolo/es

Moreno, I.

2004 Globalización, mercado, cultura e identidad”. En: P. Moreno Feliu (Comp.), Entre las gracias y el molino satánico: Lecturas de Antropología Económica (cap. 21). Madrid: UNED.

Olson, D. R.

1998 El mundo sobre el papel. El impacto de la escritura y la lectura en la estructura del conocimiento. Barcelona: Gedisa.

Sandkühler, H.J.

1999 Mundos posibles. El nacimiento de una nueva mentalidad cientifica. Madrid: Akal.

Stocking, G.W.

2003 La magia del etnógrafo. El trabajo de campo en la antropología británica desde Tylor a Malinoswski. En: H. Velasco, F.J. García y Á. Díaz de Rada (Eds.), Lecturas de Antropología para educadores. El ámbito de la Antropología de la Educación y de la Etnografía Escolar (pp. 43-93). Madrid: Trotta.

Uribe, Fernando

1998 Evaluación ecológica rápida del Darién. Medellín: Universidad de Antioquia.

Uribe, Fernando (Coord. general), et al.

1999 Caracterización ambiental del Darién colombiano. Dimensión social. Medellín: CISH y F. Natura, y U. de Antioquia. 
Universitas, Revista de Ciencias Sociales y Humanas de la Universidad Politécnica Salesiana del Ecuador, Año XIII, No. 22, 2015

Velasco, Honorio y Ángel Díaz de Rada

2003 La lógica de la investigación etnográfica. Un modelo de trabajo para etnógrafos de escuela. Madrid: Trotta.

Fecha de recepción: 18/3/2015; fecha de aprobación: 12/5/2015 